\title{
Project Study Program Development and Satisfaction Survey for Premedical Years at a medical school in Korea
}

\author{
Soo-Koung Jun ${ }^{1}$ \\ ${ }^{1}$ Institute of Education, University of London
}

\begin{abstract}
The aim of this study was to develop and describe the implementation of the project study program using an evaluation tool with portfolio in the premedical course. In 2006 the structured questionnaire was given out to 46 students in order to explore their opinions and satisfaction. This course was implemented at the first semester of the year premedical year), featured with small group activities, selection of a research theme of any kind and carrying it out for one semester. Students did not responded positively to the satisfaction survey questionnaires, which was in average around 3.5 in 5 point Likert scale. Students reported that it was beneficial to implement a research and write a paper while they felt more difficult to select the research themes by themselves mainly because of their limited opportunity of independent study. This project study program utilizing a portfolio technique was needed to be developed in a way to boost up the satisfaction level of students. It is expected that in the further research, the effectiveness of this program which would develop students' learning ability in the cooperation with other students as a team and their attitude of valuing the process than the result through portfolio evaluation should be testified.
\end{abstract}

Keywords: Portfolio. Project study Program, Premedical Course, PBL

\section{Introduction}

In Korea, many medical schools have introduced the Problem-Based Learning (PBL) programs in order to train physicians with active and problem-solving ability. It designs to cope with the limitation of lecture-based learning in a way that a group of students discuss and cooperate each other to solve out a problem. Also, at E medical school, from 2005, PBL has introduced in the formal curriculum. However, some difficulties and limitation of PBL applications were found. First, students were not accustomed to discussion method in a group. Second, they were not good at cooperative learning in the process of solving a problem with friends. Thus, it is needed to provide an opportunity with that students could develop their discussion and cooperative learning climate before joining in PBL. With this context, E medical school designed the 'project-study' in a group in which students could carry out a research project. The group project is a sort of learning model in which each student belongs to a group and could learn how to obtain information and knowledge, and how to organize it (Blumenfeld, 1991; Sinclair, 1999). In addition, this program designed by E medical school used the portfolio evaluation method, so the process of the project, not only the result, could be evaluated (Challis, 1999; Smith \& Tillema, 2003).

\section{Method}

First, the program was developed by 3 professors: procedure, content, grouping method, the role of teacher and student, tutorial method, and evaluation method including portfolio. Second, after the implementation of the program, student opinion survey was carried out in 2006. In 2006, the structured questionnaire was 
made with 5-likert scale. Each year, 42 students participated in the survey.

\section{Results}

\subsection{Program development and stu- dent evaluation}

The specific procedures and content of the program is shown in Table 1 . In the orientation time, the purpose of the program was explained and 8 groups were randomly organized (5 students in a group). Students were encouraged to select their own research subject, to plan how to led their research, and then they had to present their planning to friends. During the implementation of the project, they met tutors for research consultation. The research result had to present again and be written as a form of dissertation. Finally, the dissertation and portfolio should be submitted. As seen in Table 2, various evaluation methods were adopted: dissertation, research plan, tutor meetings, result presentation, peer evaluation, tutor evaluation about student's attitude, and portfolio. The students' dissertations were collected in a book and their portfolios were displayed.

\section{Table 1 Procedure of project-study}

\begin{tabular}{|c|c|}
\hline Steps & Process \\
\hline \multirow{3}{*}{ Induction } & Orientation \\
\hline & Grouping \\
\hline & $\begin{array}{l}\text { Discussion on implementing } \\
\text { the process }\end{array}$ \\
\hline$\downarrow$ & $\downarrow$ \\
\hline \multirow{3}{*}{$\begin{array}{l}\text { Research ques- } \\
\text { tions and plan- } \\
\text { ning }\end{array}$} & Research questions \\
\hline & Assigning of the project \\
\hline & Presenting of study planning \\
\hline$\downarrow$ & $\downarrow$ \\
\hline \multirow{2}{*}{ Implementation } & Research review \\
\hline & Research consultation \\
\hline$\downarrow$ & $\downarrow$ \\
\hline Presentation & Composing results of the \\
\hline
\end{tabular}

\begin{tabular}{|c|c|}
\hline & \begin{tabular}{|l|} 
project \\
Presenting results of project
\end{tabular} \\
\hline$\downarrow$ & $\downarrow$ \\
\hline \multirow{3}{*}{$\begin{array}{l}\text { Writing up dis- } \\
\text { sertation }\end{array}$} & Abstract writing \\
\hline & Peer review I, II \\
\hline & Dissertation consultation \\
\hline$\downarrow$ & $\downarrow$ \\
\hline \multirow{3}{*}{$\begin{array}{l}\text { Submission and } \\
\text { feedback }\end{array}$} & Submitting dissertation \\
\hline & Submitting portfolio \\
\hline & Opinion survey \\
\hline
\end{tabular}

Table 2 Evaluation methods

\begin{tabular}{ll}
\hline Items & Pecentage \\
\hline Dissertation & $15 \%$ \\
Research plan & $10 \%$ \\
Tutor meeting & $15 \%$ \\
Result presentation & $15 \%$ \\
Peer evaluation & $10 \%$ \\
Tutor evaluation about & $10 \%$ \\
student's attitude & $15 \%$ \\
Portfolio & $100 \%$ \\
\hline Total & \\
\hline
\end{tabular}

\subsection{Student's satisfaction survey}

After the implementation of the program in 2006, the opinion survey was carried out (see Table 3 ). The survey was made 5 likert scale from 1 least agree to 5 most agree. Student reported they were satisfied with the program in general $(\mathrm{M}=3.44)$. They were the most positive in the question 'is the program recommendable to junior members?'( $M=3.67)$. Students also were positive in obtaining 9 skills through this program $(M=3.59)$, and in particular, they reported that this project study was good for improving cooperative learning skills $(\mathrm{M}=3.81)$. 
Table 2 Students' Satisfaction and Self' Reported Achievements by This Program

\begin{tabular}{|c|c|c|}
\hline Category & Items & $\begin{array}{l}\text { Mean } \pm \\
\text { SD }\end{array}$ \\
\hline \multirow{5}{*}{ Satisfaction } & Is it interesting? & $\begin{array}{l}3.38 \pm \\
0.96\end{array}$ \\
\hline & $\begin{array}{l}\text { Is the evaluation appro- } \\
\text { priate? }\end{array}$ & $\begin{array}{l}3.24 \pm \\
0.95\end{array}$ \\
\hline & Is the tutor effective? & $\begin{array}{l}3.52 \pm \\
0.91\end{array}$ \\
\hline & $\begin{array}{l}\text { Are you satisfied with it } \\
\text { more than just lecturing? }\end{array}$ & $\begin{array}{l}3.40 \pm \\
0.91\end{array}$ \\
\hline & $\begin{array}{l}\text { Is it recommendable to } \\
\text { junior members? }\end{array}$ & $\begin{array}{l}3.67 \pm \\
0.92\end{array}$ \\
\hline \multirow{9}{*}{$\begin{array}{l}\text { List of gain- } \\
\text { ing ability } \\
\text { through the } \\
\text { program }\end{array}$} & $\begin{array}{l}\text { Self-directed learning } \\
\text { habit }\end{array}$ & $\begin{array}{l}3.24 \pm \\
0.87\end{array}$ \\
\hline & Peer cooperation & $\begin{array}{l}3.81 \pm \\
0.83\end{array}$ \\
\hline & $\begin{array}{l}\text { Research procedure } \\
\text { and methods }\end{array}$ & $\begin{array}{l}3.67 \pm \\
0.92\end{array}$ \\
\hline & $\begin{array}{l}\text { Research paper writing } \\
\text { skill }\end{array}$ & $\begin{array}{l}3.79 \pm \\
0.68\end{array}$ \\
\hline & Discussion skill & $\begin{array}{l}3.60 \pm \\
0.85\end{array}$ \\
\hline & Presentation skill & $\begin{array}{l}3.33 \pm \\
0.92\end{array}$ \\
\hline & Listening skill & $\begin{array}{l}3.31 \pm \\
0.86\end{array}$ \\
\hline & Responsibility & $\begin{array}{l}3.79 \pm \\
0.78\end{array}$ \\
\hline & Teamwork & $\begin{array}{l}3.79 \pm \\
0.84\end{array}$ \\
\hline
\end{tabular}

\section{Conclusion}

The group project study developed by $\mathrm{E}$ medical school was effective in terms of exposing premedical students to the discussion and cooperative learning climate before the application of PBL. In general, participants reported that this program was interesting; evaluation was appropriate; tutor was helpful; they were satisfied with it more than lecture program; and it was also recommendable to junior students. In addition, they were positive in gaining abilities through this program such as cooperation, research procedure and methods, research paper writing skill, discussion skill, listening skill, presentation skill, responsibility and teamwork. 3 tutors, who participated in this project, reported that they spent more time and energy in carrying out this program than giving a lecture and also they had to cooperate with the same principles and methods in tutoring. For the continuous development of this program, tutor training program should be developed to guide small group and consult students' dissertation and presentation.

\section{Reference}

[1] Blumenfeld, P. (1991). Motivating project-based learning: sustaining the doing, supporting the learning. Educational Psychologist, 26, 369-398.

[2] Challis, M. (1999). AMEE Medical edcuation guide No. 11 (revised): portfolio-based learning and assessment in medical education. Medical Teacher, $21(4), 370-385$.

[3] Shepard, L.A. \& Bliem, C.L.(1995). Parent's thinking about standardized tests and performance assessments. Educational Researcher, 24(8), 25-32.

[4] Smith, K. \& Tillema, H.(2003). Clarifying different types of portfolio use. Assessment \& Evaluation in Higher Education, $28(6), 625-648$.

[5] Sinclair, M. (1999). Project-based learning in midwifery education. The Practising midwife, 2(2), 19-22. 